\title{
The analysis of vibrations in the vehicle with naturally aspirated and turbocharged gasoline engine
}

\begin{abstract}
In this paper, the author presents a study of vibrations in a passenger vehicle and the possible influence on driver's body in the process of natural operation. The author describes the dependence of engine size and additional equipment as the possible primary source of the vibration variations and their further propagation in the entire vehicle structure. The analysis was performed on the passenger cars with naturally aspirated and turbocharged gasoline engines. The aim of this study was to verify the level of vibrations in the vehicle structure with these particular engines, especially influence of downsized power unit, during various state of engine operation. The second goal was to examine the vibrations in the specified location related to driver's body. The measuring method used piezoelectric accelerometers, which were attached to the designated locations in the vehicle and were able to detect variations of the acceleration. The signals were collected as characteristics in the time domain. In order to achieve frequency domain for spectral analyses, the author applied the Fast Fourier Transform (FFT).
\end{abstract}

Key words: vehicle, vibration, engine, downsizing, fast Fourier transform, accelerometry

\section{Introduction}

Nowadays, the most challenging task for every car manufacturer is to fulfill environment regulations imposed by governments and among others, the European Union. Restricted requirements for toxic products emission trigger additional actions which every car company has to take into consideration from the beginning of the new project for a new vehicle release $[1,2]$.

The problem with the current approach to emission regulations is that they focus strongly on the one aspect of harmful emission from engine combustion and its impact on the environment, while not covering the others enough.

One of those aspect is the vibrations which are the inseparable characteristic for every running light and heavy machinery. The measured type and level of vibrations can display technical condition much easier, faster and more precisely than the traditional disassembly inspection.

Vibrations have significant impact on two major aspects. The first one is a degradation of the machine, which can lead to malfunction and eventually serious failure [3]. The second one is the potential harmful effects on the human body, which can cause discomfort during the operation or even the vibrational disease [4].

The existing tests before every car production launch show, that besides the Euro NCAP crush tests, there is no sufficient research about essential effects on people in the car while everyday operation, excluding unexpected and rare events, such as road accidents.

The review of recent exemplary studies [5-8] describe the test methodologies in this subject, yet they do not cover this issue entirely. They most often focus on one aspect during the tests, neglecting the state and technical description of the car. They also do not have specified various measurement locations for sensors related to people in the vehicle, especially the driver.

There is an apparent lack of advanced researches into vibrations which affect human's body during operation of passenger vehicles. The author would like to broaden the view for this subject and fill in the gap on this significant matter.
This paper presents the introduction of author's approach for vehicle testing in regard to vibrations occurring in the car structure during the driving, which could have vital influence on driver's body.

The author considers these studies as essential in regard to vibroacoustic measurements for passenger cars and a development of methodology comparing to current researches. Moreover, the author indicates the importance of verification for the new generation of small, high power engines equipped with high-speed turbochargers. This validation should evaluate whether those engines have possible harmful effects on vehicle users.

The purpose of this study is to verify the utility of this measuring method and furthermore, the author would like to examine vibroacoustic emission in different cars, distinctive in various categories, such as year of manufacture, engine size and auxiliary equipment.

This could lead to important correlations between indicated variables and displays potentially dangerous factors for users.

\section{Measurements}

\subsection{Investigated objects}

The examinations were performed on the two similar cars from different model generations. The first one is Seat Leon 11.6 and the second one is Seat Leon 31.4 TSI. The gasoline engines had comparable power and torque. The Seat Leon 3 was equipped with turbocharger. The smaller engine belongs to recent trend of engine design in the car industry, where engine capacity is decreased while at the same time the power is maintained at the same level by addition of auxiliary

Table 1. Cars specification $[4,5]$

\begin{tabular}{|l|c|c|}
\hline & Seat Leon 1 1.6 & Seat Leon 3 1.4 TSI \\
\hline YoM & 2004 & 2018 \\
\hline Mileage $[\mathrm{m}]$ & 208000 & 73000 \\
\hline Power $[\mathrm{HP}]$ & 105 & 125 \\
\hline Torque $[\mathrm{Nm}]$ & 148 & 200 \\
\hline Auxiliary & - & Turbocharger \\
\hline
\end{tabular}




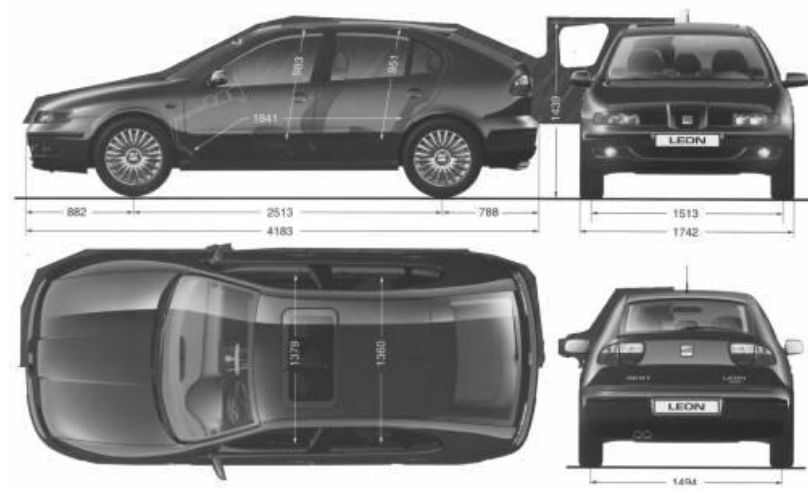

Fig. 1. Seat Leon 1 body overview [6]
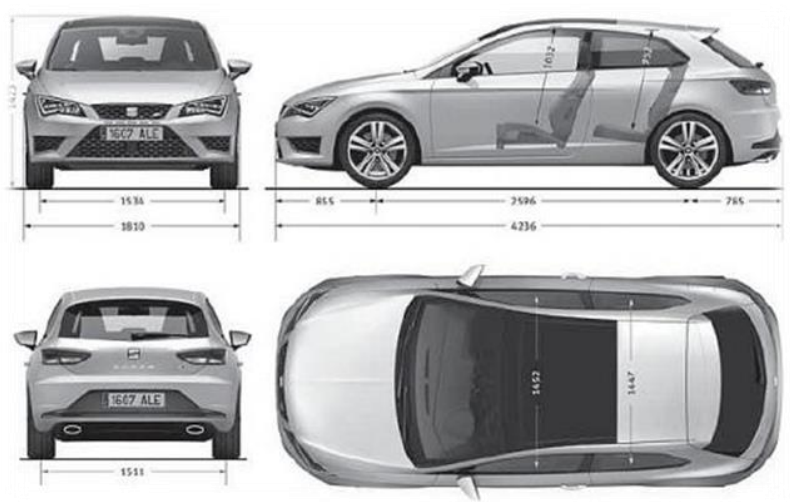

Fig. 2. Seat Leon 3 body overview [7]

\subsection{Measurement system}

For the purpose of this research, there was chosen the non-invasive measurement method using piezoelectric accelerometers. It utilizes the piezoelectric effect, which is occurrence of the electric potential on the surface of the piezoelectric material, which is caused by the material deformation, alongside with the applied force [8].

During the mechanical vibrations the kinetic energy of the material surface is converted into potential energy and vice versa [9]. The force which causes the surface displacement effects on attached sensor. Inside the sensor, the mentioned crystal is exposed to inertia, which allows obtain certain acceleration of vibrating object surface [10].

The measuring system consisted of the PCB Piezotronics single axis sensors, model 352C04 (Table 2).

The input module was National Instruments 4-Channel Dynamic Signal Acquisition Module, model NI-9234 (Table 3).

Table 2. PCB Piezotronics Accelerometer 352C04 specification [11]

\begin{tabular}{|l|c|}
\hline \multicolumn{2}{|c|}{ PCB Piezotronics Accelerometer 352C04 } \\
\hline Sensitivity & $10 \mathrm{mV} / \mathrm{g}( \pm 10 \%)$ \\
\hline Measurement Range & $\pm 500 \mathrm{~g} \mathrm{pk}$ \\
\hline Frequency Range & 0.5 to $10000 \mathrm{~Hz}( \pm 5 \%)$ \\
\hline Broadband Resolution & $0.0005 \mathrm{~g} \mathrm{rms}$ \\
\hline
\end{tabular}

Table 3. National Instruments Module NI-9234 specification [12]

\begin{tabular}{|l|c|}
\hline \multicolumn{2}{|c|}{ National Instruments Module NI-9234 } \\
\hline Signal Ranges & $\pm 5 \mathrm{~V}$ \\
\hline Input Impedance & $305 \mathrm{k} \Omega$ \\
\hline Frequency Range & $51.2 \mathrm{kHz}$ \\
\hline Accuracy & $\pm 50 \mathrm{ppm}, \pm 0.006 \%, 0.3 \mathrm{mV}$ \\
\hline Frequency Range & 0.5 to $10000 \mathrm{~Hz}( \pm 5 \%)$ \\
\hline Broadband Resolution & $0.0005 \mathrm{~g} \mathrm{rms}$ \\
\hline
\end{tabular}

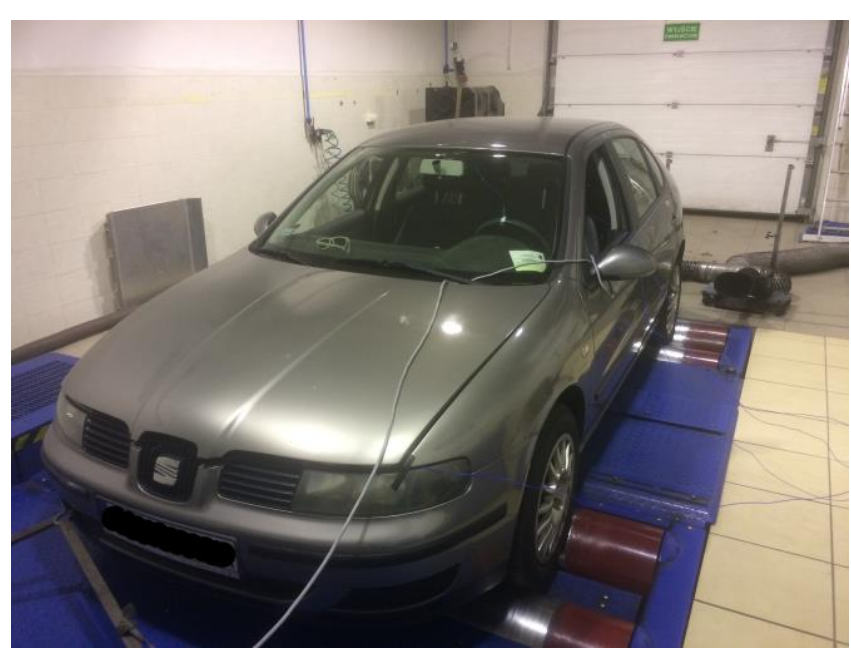

Fig. 3. Test bench for vibration measurements

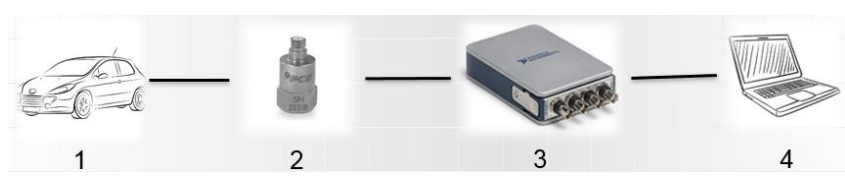

Fig. 4. Functional diagram for accelerometric measurements: 1 - vehicle,

2 - accelerometer, 3 - vibration signal input module, 4 - computer

\subsection{Measurement methodology}

The examination was performed on the dyno MAHA LPS 3000 [18]. The vehicle was prepared for examination as it is shown in Fig. 3 and connected with measuring equipment (Fig. 4). The ambient temperature was set to the room temperature. The cars were technically fit and prerunning before measurements to obtain the proper working oil temperature.

The ISO 2631-1:1997 [19] describes evaluation of human exposure to whole body vibration as well as the Polish equivalent standard PN-EN 14253:2005 [20]. Both of them present the subject in general manner, not focusing on particular cases.

Another Polish standard PN-91/S-04100 [21] describes methodology and evaluation of vibrations at the workplace in vehicles. This requirement presents more specific approach for vibration measurements, however the author did not consider this one as covering the whole subject entirely.

For that reason, the author decided to develop original approach for vibration measurements, which would extend and supplement current standards.

The existing studies [22] proves that vertical direction of measurements contains significantly lower frequency range of signal, which is the most important regarding the influence on human body.

The author selected two measurement points: on the engine mount and on the steering wheel. The locations were related to driver's body parts exposed for vibrations in his seated position in the car. The sensors were positioned vertically, along the gravitational force vector direction.

There were specified particular states for every run, in which the cars were being measured. The velocities (30 $\mathrm{km} / \mathrm{h}, 50 \mathrm{~km} / \mathrm{h}, 90 \mathrm{~km} / \mathrm{h}$ ) were chosen as the most popular, operational speeds which the vehicles are frequently driven. 
For every speed, the signals where collected on two selected gears. (Table 4 and 5).

The methodology for conducted research is designed to be comparative, therefore all measurement errors are considered as systematic and not taken into result calculations.

Table 4. Car cases specification - Leon 1

\begin{tabular}{|c|c|c|c|}
\hline \multicolumn{5}{|c|}{ Seat Leon 1} \\
\hline & $30 \mathrm{~km} / \mathrm{h}$ & $50 \mathrm{~km} / \mathrm{h}$ & $90 \mathrm{~km} / \mathrm{h}$ \\
\hline 2 gear [rev/min] & 2180 & - & - \\
\hline 3 gear [rev/min] & 1530 & 2550 & - \\
\hline 4 gear [rev/min] & - & 1920 & 3420 \\
\hline 5 gear [rev/min] & - & - & 2820 \\
\hline
\end{tabular}

Table 5. Car cases specification - Leon 3

\begin{tabular}{|c|c|c|c|}
\hline \multicolumn{5}{|c|}{ Seat Leon 3} \\
\hline & $30 \mathrm{~km} / \mathrm{h}$ & $50 \mathrm{~km} / \mathrm{h}$ & $90 \mathrm{~km} / \mathrm{h}$ \\
\hline 2 gear [rev/min] & 1980 & - & - \\
\hline 3 gear [rev/min] & 1310 & 2170 & - \\
\hline 4 gear [rev/min] & - & 1650 & 2960 \\
\hline 5 gear [rev/min] & - & - & 2370 \\
\hline
\end{tabular}

\subsection{Signal processing}

The character of signals received from engine as a primary source of vibrations is considered as stationary. The stochastic processes are stationary when the arithmetic mean, variance and autocorrelation do not change in time. The signals were transformed with the Fast Fourier Transform (FFT), which is a very effective tool for processing this type of signals [23].

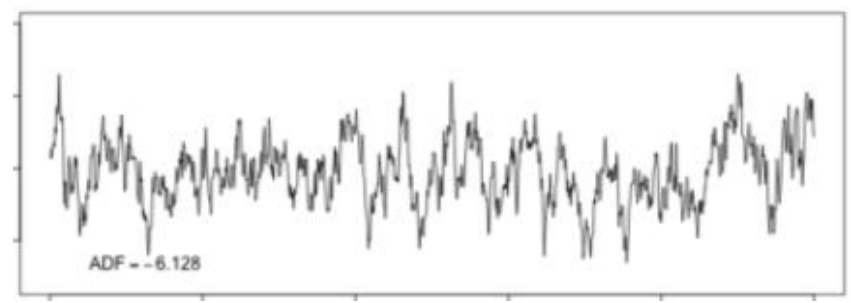

Fig. 5. The stationary signal [24]

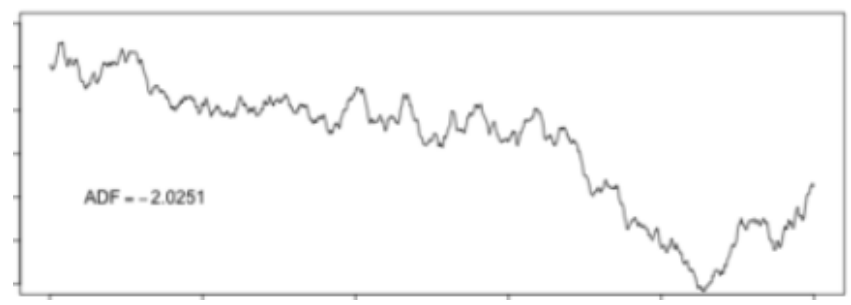

Fig.6. The non-stationary signal [24]

\section{Results}

The vibration signals were registered as plots of a voltage in time domain. The postprocessing based on FFT in order to obtain spectra in a frequency domain. The waveforms recorded for the 2 seconds were taken for the analysis. The sampling frequency equated $2048 \mathrm{~Hz}$.

Vibration signals were recognized as the stationary type, which supported the statement, that the engines have stationary characteristics of running. Such sampling frequency allowed to receive large amount of measurement samples and it was sufficient to perform the FFT for receiving the spectra for further analysis [13].

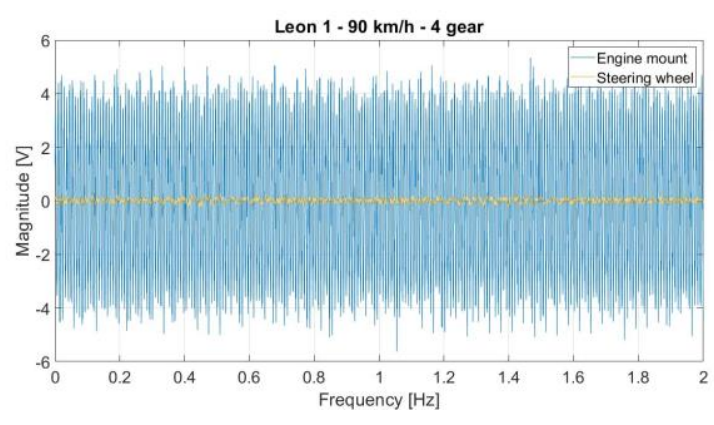

Fig. 7. Time course of the two sensors in the Leon 1

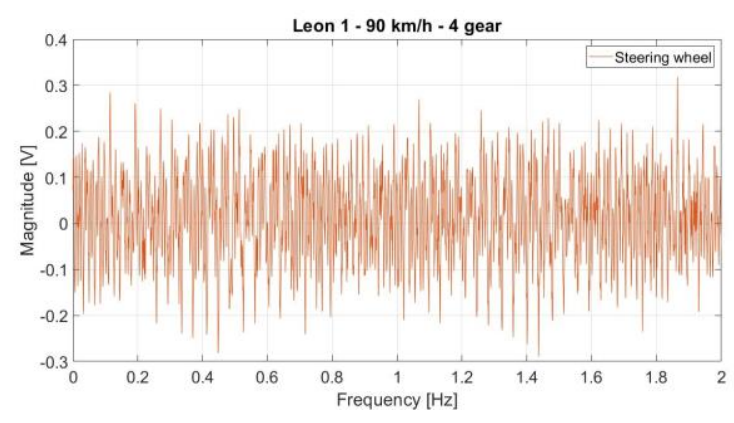

Fig. 8. Time course of the steering wheel sensor in the Leon 1

As it can be seen in the diagram above (Fig. 7), the signal from the engine mount in the Leon 1 has significantly larger amplitude in compare to the other. The same can be observed in the Leon 3 (Fig. 9). It can be understood as the engine is one of the main source of the vibrations in the car and the another location for the sensor is damped.

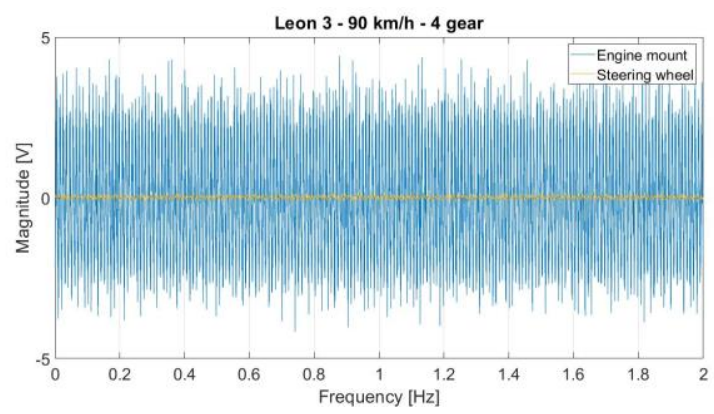

Fig. 9. Time course of the two sensors in the Leon 3

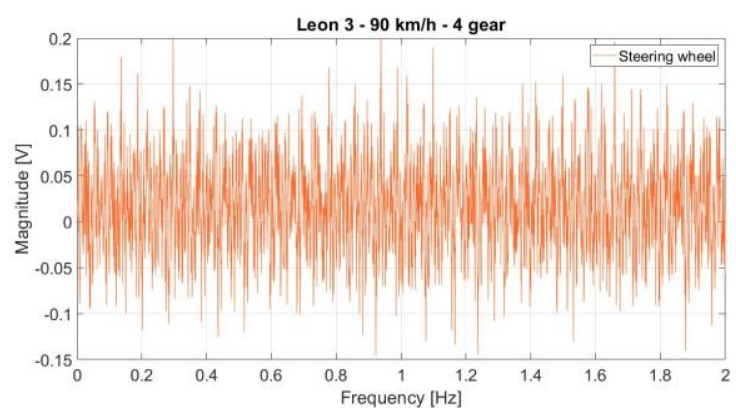

Fig. 10. Time course of the steering wheel sensor in the Leon 3 
The location on steering wheel is the one of the places, where the constant contact between the driver and the vehicle is.

The spectra for both cars were compared in order to distinguish the differences between the vehicles and the influence of downsized engine on vibration frequencies.

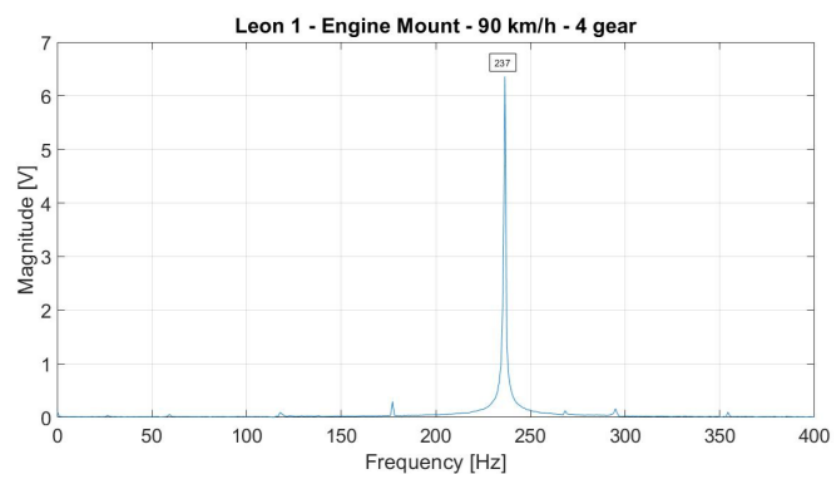

Fig. 11. Spectrum of the engine mount sensor in the Leon 1

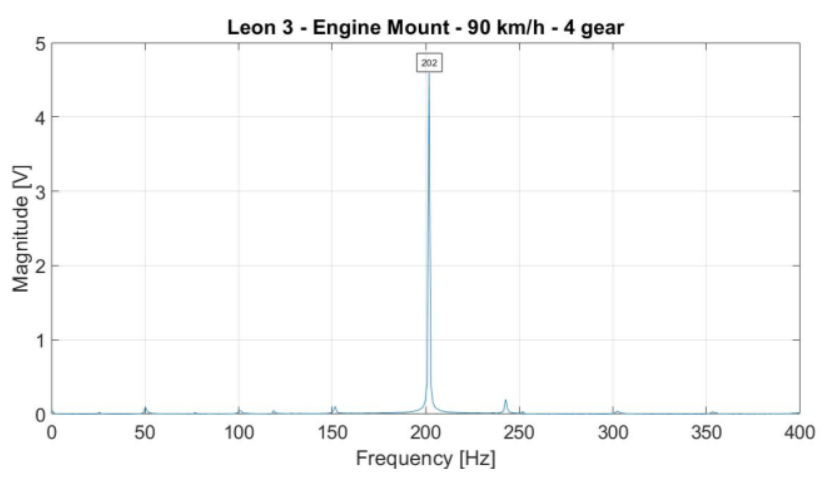

Fig. 12. Spectrum of the engine mount sensor in the Leon 3

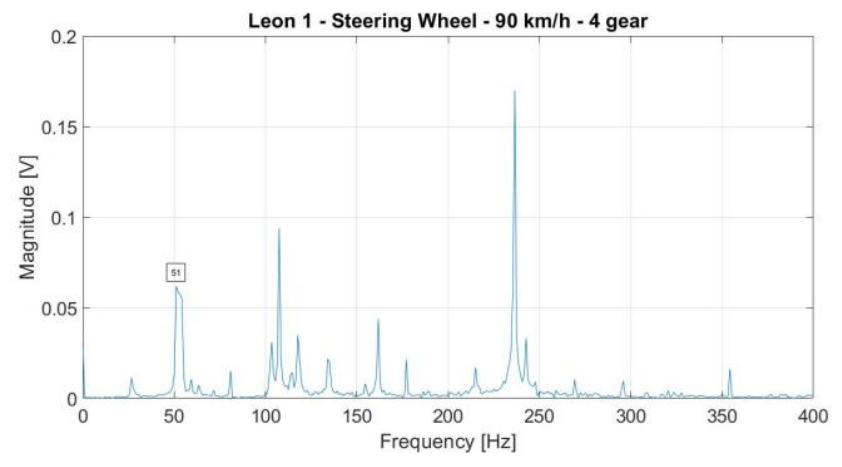

Fig. 13. Spectrum of the steering wheel sensor in the Leon 1

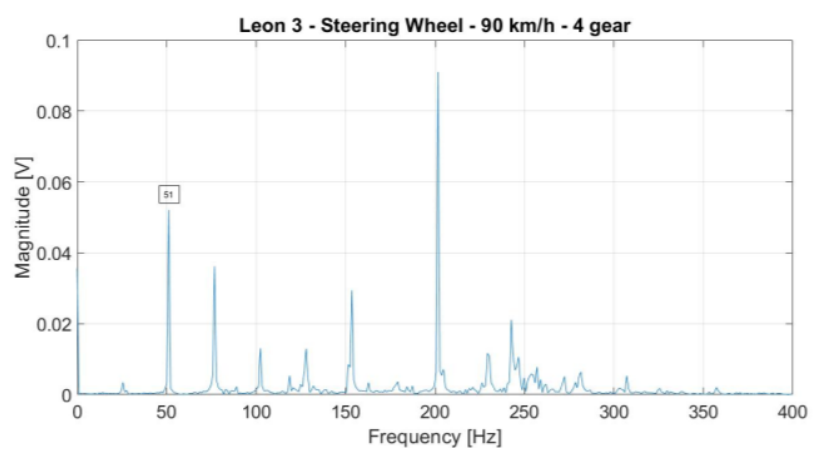

Fig. 14. Spectrum of the steering wheel sensor in the Leon 3

In the diagrams above (Fig. 11-14) it can be seen the examples of spectra for engine mount and steering wheel for both cars. The author focused on comparing only the dominant harmonics of the original signal. The complete results for these two locations for every case of the measurements are presented below (Table 6 and 7).

Table 6. Frequencies for the engine mount

\begin{tabular}{|c|c|c|c|c|c|c|}
\hline & \multicolumn{6}{|c|}{ Engine mount } \\
\cline { 2 - 7 } & $30 \mathrm{~km} / \mathrm{h}$ & $50 \mathrm{~km} / \mathrm{h}$ & $90 \mathrm{~km} / \mathrm{h}$ \\
\hline Gear & 2 & 3 & 3 & 4 & 4 & 5 \\
\hline Leon 1 [Hz] & 147 & 106 & 175 & 132 & 237 & 194 \\
\hline Leon 3 [Hz] & 137 & 89 & 148 & 112 & 202 & 161 \\
\hline
\end{tabular}

Table 7. Frequencies for the steering wheel

\begin{tabular}{|c|c|c|c|c|c|c|}
\hline & \multicolumn{6}{|c|}{ Steering wheel } \\
\cline { 2 - 7 } & \multicolumn{2}{|c|}{$30 \mathrm{~km} / \mathrm{h}$} & \multicolumn{2}{|c|}{$50 \mathrm{~km} / \mathrm{h}$} & \multicolumn{2}{c|}{$90 \mathrm{~km} / \mathrm{h}$} \\
\hline Gear & 2 & 3 & 3 & 4 & 4 & 5 \\
\hline Leon 1 [hz] & 53 & 54 & 60 & 60 & 51 & 54 \\
\hline Leon 3 [hz] & 8 & 8 & 43 & 43 & 51 & 51 \\
\hline
\end{tabular}

\section{Conclusions}

This introduction study shows, that accelerometry is a valid methodology for author's approach on vibrations measurements in the passenger vehicles.

The measurements of vibrations generated by the engine display, that waveform signals have stationary characteristic, therefore the Fast Fourier Transform is legitimate method for measurements and provides meaningful results.

The amplitude in time domain of the engine mount signal, as it is the primary source of vibrations for this study, is much higher than the location on the steering wheel, which shows the damping effect.

The results for the engine location for both cars show that the frequencies are higher with the increase of velocity. The higher gear of each speed decreases the frequency. The turbocharged engine has lower frequencies than naturally aspirated one in all cases of velocity and gear combination.

The results for the steering wheel location in the car with turbocharged engine show, that frequencies for two velocities are lower than in the another one and for one velocity are equal. The change of gear in this case does not have any impact for frequency value.

This study shows that the engine manufactured in the downsized technology, equipped with turbochargers, can have more negative or harmful effects on the driver, due to existence of lower frequencies than the car with naturally aspirated engine.

Currently available information about vibrations influence on human body show, that lower frequencies are the most dangerous for people, however the exact limits are not officially established and can vary depending on each person.

The author would like to continue studies and development of this methodology with higher number of vehicles and additional measurement locations verifying the observed tendency on the larger research sample.

The author acknowledges the huge necessity for further studies of possibly harmful effects of low frequencies occurring in the passenger vehicles. 


\section{Nomenclature}

TSI Turbo Stratified Injcetion

YoM Year of Manfacture

FFT Fast Fourier Transform
HP Horse Power

Euro NCAP European New Car Assessment Programme

\section{Bibliography}

[1] Commission Regulation (EC) No 692/2008 of 18 July 2008 implementing and amending Regulation (EC) No 715/2007 of the European Parliament and of the Council on typeapproval of motor vehicles with respect to emissions from light passenger and commercial vehicles (Euro 5 and Euro $6)$ and on access to vehicle repair and maintenance information.

[2] Regulation (EU) 2019/631 of the European Parliament and of the Council of 17 April 2019 setting $\mathrm{CO}_{2}$ emission performance standards for new passenger cars and for new light commercial vehicles, and repealing Regulations (EC) No. 443/2009 and (EU) No 510/2011.

[3] SCHEFFER, C., GIRDHAR, P. Practical machinery vibration analysis and predictive maintenance (Practical Professional). Newnes. 2004.

[4] WORLD HEALTH ORGANIZATION. Occupational exposure to vibration from handheld tools. UMEA Universitet.

[5] BURDZIK, R., KONIECZNY, L. Vibration issues in passenger car. Transport Problems. 2014, 9(3), 83-90.

[6] BURDZIK, R., KONIECZNY, L. Application of vibroacoustic methods for monitoring and control of comfort and safety of passenger cars. Solid State Phenomena. 2014 210, 20-25.

[7] KUMARESH, S.A., ALADDIN, M.F. A study of vibration transmission on seated person in passenger vehicle. AIP Conference Proceedings. 2019, 2137(1).

[8] NAHAVI, H., FOULADI, M.H., NOR, M.J.M. Evaluation of whole-body vibration and ride comfort in a passenger car. International Journal of Acoustic and Vibration. 2009, 14(3).

[9] https://www.autocentrum.pl/dane-techniczne/seat/leon/i/ hatchback/silnik-benzynowy-1.6-105km-2000-2004/
[10] https://www.autocentrum.pl/danetechniczne/seat/leon/iii/hatchback-facelifting/silnikbenzynowy-1.4-tsi-125km-2016-2018/

[11] https://www.theblueprints.com/blueprints/cars/seat/985/view/seat_leon/

[12] https://m.autocentrum.pl/ac-file/carblueprint/578cd964582c7db4438baba3/szkic-technicznyseat-leon-iii-cupra-sc.jpg

[13] CADY, W.G. Piezoelectricity: volume one and two: an introduction to the theory and applications of electromechanical phenomena in crystals. Dover Publications. 2018.

[14] DE SILVA, C. Vibrations Fundamentals and Practice. CRC Press, NY 2000.

[15] GIERGIEL, J. Mechanical vibrations (in Polish). University Scientific-Educational Publishers, Cracow 2000.

[16] https://www.pcb.com/products?m=352C04

[17] https://www.ni.com/pdf/manuals/374238a_02.pdf

[18] Hamownia podwoziowa do kontroli mocy MAHA LPS 300 dla samochodów osobowych, Instrukcja obsługi.

[19] ISO 2631-1:1997 Mechanical vibration and shock - Evaluation of human exposure to whole-body vibration - Part 1 : general requirements.

[20] PN-EN 14253:2005 Drgania mechaniczne. Pomiar i obliczanie zawodowej ekspozycji na drgania o ogólnym działaniu na organizm człowieka dla potrzeb ochrony zdrowia. Wytyczne praktyczne.

[21] PN-91/S-04100 Drgania. Metody badań i oceny drgań mechanicznych na stanowiskach pracy w pojazdach.

[22] ŁAZARZ, B., MADEJ, H., CZECH, P. Fotel kierowcy jako element układu thumienia drgań. Transport. 2009, 65, Zeszyty Naukowe Politechniki Śląskiej.

[23] BRIGHAM, E. Fast Fourier Transform and its applications, Pearson, 1988.

[24] pl.wikipedia.org/wiki/Plik:Stationarycomparison.png

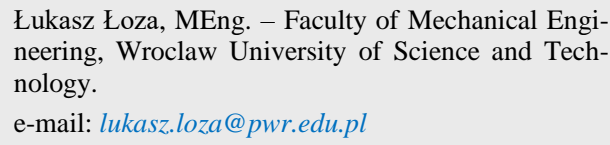

